\title{
NILAI KEMANUSIAAN DALAM BINGKAI PLURALISME DAN MULTIKULTURALISME DALAM KOMIK “SANDHORA" (1970) KARYA TEGUH SANTOSA
}

\author{
Aditya Nirwana ${ }^{1}$, Daniel Ginting ${ }^{2}$ \\ ${ }^{1}$ Program Studi Desain Komunikasi Visual, Fakultas Sains dan Teknologi, Universitas Ma Chung \\ ${ }^{2}$ Program Studi Sastra Inggris, Fakultas Bahasa dan Seni, Universitas Ma Chung \\ aditya.nirwana@machung.ac.id ${ }^{1}$, daniel.ginting@machung.ac.id ${ }^{2}$
}

\begin{abstract}
Abstrak
Wajah perkomikan di Indonesia sangat dipengaruhi oleh kondisi zaman. Komik "Sandhora" tidak hanya mengungkapkan gejala-gejala seniman penciptanya, namun juga merefleksikan kondisi sosio-kultural pada masa itu dan pemikiran ideologis kebudayaan Nusantara, dan patut diduga memiliki komitmen yang kuat terhadap paradigma estetik humanisme universal. Tujuan penelitian ini adalah mendeskripsikan makna primer, sekunder dan intrinsik yang membentuk dunia motif artistik, gambar komik, dan nilai simbolik dalam komik "Sandhora" (1970) karya Teguh Santosa. Dengan menggunakan metode sejarah dan pendekatan teori ikonografi dan ikonologi Erwin Panofsky, penelitian ini menemukan bahwa secara faktual komik ini menceritakan tentang kisah cinta antara dua tokoh utama yang penuh dengan konflik, ketegangan, pertarungan antara hidup dan mati, kelicikan, kekesatriaan, dan harapan, yang diekspresikan melalui hubungan antar elemen/unsur komik. Tema yang diangkat dalam Komik "Sandhora" ini adalah kemanusiaan dalam konteks pluralisme dan multikulturalisme dengan setting Indonesia. Tema komik ini menunjukkan betapa kuatnya komitmen terhadap paradigma estetik Humanisme Universal, yang populer pada paruh kedua 1960-an hingga tahun 1980-an. Komik "Sandhora" karya Teguh Santosa ini merupakan kristalisasi simbol dari pembelaan terhadap nilai-nilai kemanusiaan/humanisme, kebebasan berekspresi, dan kesetaraan manusia, serta upaya perjuangan budaya dalam rangka mempertahankan dan mengembangkan martabat diri bangsa Indonesia di tengah masyarakat global.
\end{abstract}

Kata Kunci: humanisme, komik, multikulturalisme, nilai, pluralism.

\begin{abstract}
Comics in Indonesia is heavily influenced by conditions of the era. "Sandhora" not just reveal symptoms of the creator, but also reflecting the socio-cultural conditions in those days and ideological thought of culture, and is suspected to have a strong commitment to the universal humanism, as aesthetic paradigm. This study aims at describing primary, secondary and intrinsic values that form artistic, pictorial, and symbolic values of "Sandhora" comic (1970) by Teguh Santosa. Using historical and iconography approaches, this study found this comic is depicting a love story of two main characters whose life is full with conflicts, tenses, struggles between life and death, craftiness, chivalry, and expectations expressed through the relationships between comic elements. The comic proposes the theme of humanity within the spirit of pluralism and multiculturalism. This themse shows author's strong commitment to the aesthetic paradigm of Universal Humanism which used to popular in the second half of the 1960 s to the 1980s. This comic also symbolizes the defense of human values/humanism, freedom of expression, and equality of human beings, as well as the efforts of cultural struggle in order to maintain and develop the dignity of the Indonesian nation in the global community.
\end{abstract}

Keywords: humanism, comic, multi-culturalism, values, pluralism. 


\section{PENDAHULUAN}

Komik, seringkali disebut juga sebagai cerita bergambar (cergam), narasi bergambar, dan belakangan muncul juga istilah 'seni sekuensial' (sequential art). Yang terakhir, seringkali digunakan secara bergantian dengan istilah komik. Pada intinya, istilahistilah tersebut dipergunakan untuk menyebut suatu bentuk karya seni yang menekankan kepada kesinambungan (continuity) gambar dan tulisan (teks) dalam mengemukakan ide atau gagasan. Eisner memberikan pengertian mengenai komik atau seni sekuensial sebagai sarana ekspresi kreatif dalam bentuk seni dan sastra yang berhubungan dengan susunan gambar atau gambar dan kata-kata untuk menceritakan sebuah cerita atau mendramatisasi ide [1]. Wajah perkomikan di Indonesia sangat dipengaruhi oleh kondisi zaman. Selama Rezim Orde Baru, penguasa senantiasa mendengungkan kebijakan pembangunan yang berkemajuan dengan dalih untuk perbaikan terhadap penyimpangan-penyimpangan yang dilakukan pemerintahan sebelumnya: kebijakan Soekarno yang 'anti-barat'. Akibatnya, bentuk-bentuk kesenian termasuk komik yang membanjiri Indonesia masa itu adalah kesenian ala barat. Tak mengherankan bila pada dekade '70-an dan '80-an dunia perkomikan Indonesia diluapi oleh terjemahan komik Amerika, Eropa dan bahkan Jepang khususnya pada dekade '90-an [2]. Hingga pada pertengahan 1990-an, munculah gerakan komik indie sebagai bentuk perlawanan terhadap hegemoni komik asing. Komik-komik independen (lokal) tersebut mencoba tampil beda: membuat gaya gambar lebih variatif dan eksperimental. Banyak komikus-komikus indie (independen) mengandalkan mesin fotokopi untuk menggandakan karya-karya mereka. Sistem distribusi ini paling banyak dilakukan di pameran komik, baik dengan jalan jual-beli atau barter antar komikus [3].

Komik Indonesia sejauh ini telah menarik perhatian beberapa peneliti. Dari hasil kajian pustaka penelitian ini ditemukan bahwa hasil penelitian tentang komik masih berkisar pada topik penilaian kualitas estetika antara komik lokal dengan komik barat [4], penyajian unsur budaya lokal dalam komik [5], dan kajian terhadap gerakan komik underground/indie [3], sementara pengkajian terhadap nilai filosofi komik sebagaimana termuat dalam makna primer, sekunder dan instrinsiknya sering diabaikan. Padahal komik jelas merupakan bagian dari seni yang memuat nilai-nilai filosofis yang dapat membangun pembaca untuk belajar sekaligus merefleksikan pemikiran dan semangat zaman saat komik itu diciptakan. Salah satu komikus terbesar Indonesia yang begitu concern terhadap pemikiran nilai-nilai simbolik semangat zaman itu adalah Teguh Santosa.

Bonneff membagi tahap-tahap evolusi komik Indonesia (periodesasi) dalam bingkai sejarah sebagai : 1) Komik era prasejarah; 2) Pengaruh barat dan China (1931-1954); 3) Kembali ke sumber kebudayaan nasional (1954-1960); 4) Periode Medan (1960-1963); 5) Komik dan nasionalisme ala Soekarno (1963-1965); 6) Masa roman remaja (19641966); 7) Mengembalikan ketertiban atas nama Pancasila (1966-1967); dan 8) Menuju stabilitas (1968-1971) [6]. Teguh Santosa, yang lahir di Malang, telah menciptakan 85 judul komik selama 58 tahun hidupnya. Jika ditempatkan pada periodisasi Bonneff tersebut, maka masa karir Teguh Santosa dapat ditempatkan pada masa Roman Remaja hingga pada masa Menuju Stabilitas. Pada dekade 70-80an, Teguh Santosa 
dapat dikatakan sebagai komikus tiga besar Indonesia, bersama Ganes TH dan Jan Mintaraga. Teguh pada masa kecilnya hidup di lingkungan grup ketoprak Kridosworo miliki keluarga besarnya, hingga kemudian grup tersebut bubar sekitar tahun 1965. Tema-tema yang dibawakan dalam komiknya pekat dengan idiom lokalitas, namun di sisi yang lain ia juga mendapatkan pengaruh dari film dan musik ala barat. Hal ini juga ditandaskan oleh Seno Gumira Ajidarma, jurnalis dan pengamat komik, mengemukakan bahwa Teguh Santosa dalam komik Mat Romeo (1971) pernah mengiklankan karya mereka dengan kata-kata "disadjikan setjara filmis dan kolosal" yang sangat relevan dengan novel bergambar. Anasir yang sama juga nampak pada cover komik Mencari Mayat Mat Pelor, disana dituliskan "pembuatan naskah ini diiringi musik original motion picture sountrack The Man With The Golden Gun".

Komik "Sandhora" (1970) yang dijadikan sebagai sumber data penelitian ini merupakan seri pertama dari serial Mat Pelor [7]. Komik ini sangat penting keberadaannya, karena karya ini mewakili periode sejarah komik Indonesia pada masa itu (dalam istilah Bonneff, periode "Menuju Stabilitas", 1968-1971) [6]. Ada sebuah tekad untuk membina kebudayaan bangsa. Komik "Sandhora" tidak hanya mengungkapkan gejalagejala seniman penciptanya, namun juga merefleksikan kondisi sosio-kultural pada masa itu dan pemikiran ideologis kebudayaan Nusantara, dan patut diduga memiliki komitmen yang kuat terhadap salah satu paradigma estetik yang pada masa-masa itu berpengaruh dalam medan seni rupa dan sastra, yakni humanisme universal.

Humanisme berasal dari latin, humanis, yang berarti manusia, dan isme berarti paham atau aliran. Istilah 'humanisme' adalah temuan dari abad ke-19. dalam bahasa Jerman kata Humanismus pertama kali diciptakan pada tahun 1908, untuk merujuk pada suatu bentuk pendidikan yang memberikan tempat utama bagi karya-karya klasik Yunani dan Latin. Adapun dalam bahasa Inggris, kata 'humanism' mulai muncul agak kemudian. Kemunculan pertama kata ini berasal dari tulisan Samuel Coleridge taylor (1812), dimana kata itu dipergunakan untuk menunjukkan suatu posisi Kristologis, yaitu kepercayaan bahwa Yesus Kristus adalah murni manusia, yang tentunya kata itu digunakan dalam konteks kebudayaan tahun 1832 [8]. Dalam Encyclopedia Britania, humanisme dipahami sebagai sebuah paham kemanusiaan, atau sebuah doktrin, tingkah laku, atau jalan hidup yang memusatkan diri pada nilai-nilai dan manusia. Adapun nilai-nilai yang terdapat dalam humanisme adalah paradigma nilai, sikap, norma, dan praktek keagamaan (religiusitas) yang mendukung kehidupan tanpa kekerasan dan damai [9]. Suseno mengungkapkan bahwa humanisme adalah sikap prinsipil dan terurai (eksplisit) yang menempatkan manusia di pusat perhatian dan sebagai titik tolak penilaian tentang kehidupan masyarakat yang baik, tuntunan intinya adalah manusia harus dihormati dalam martabatnya [10]. Adapun kemanusiaan merupakan sikap yang diharapkan oleh gerakan humanisme tersebut, yakni cita-cita pengembangan kemanusiaan dan bakat-bakat hati dan jiwa manusia secara selaras dan seimbang, mengembangkan budaya dan keluhuran pikiran, cita-cita itu terungkap dalam sikap yang terbaik dan berbesar hati terhadap sesama manusia. Humanisme pada dasarnya dalah suatu gerakan pendidikan dan kebudayaan yang didasarkan atas pembaruan ilmu sastra, dengan hasilnya bahwa sebagian besar humanis awal abad ke- 
16 adalah pendidik profesional. Humanisme menaruh minat pada kefasihan, baik tulisan maupun tuturan. Retorika dengan demikian dipelajari sebagai sarana untuk mencapai tujuan ini [8]. Hadi mengungkapkan bahwa humanisme dalam hal toleransi mempunyai prinsip-prinsip mengenai kemungkinan hidup rukun antar penganut atau pemeluk berbagai macam agama. Para humanis memegang teguh semangat persaudaraan sebagai satu pandangan kolektif yang prinsipil dalam semua keyakinan agama.Pandangan itu memiliki tujuan terhadap perdamaian agama secara universal. Humanisme sebagai sautu gerakan, membangkitkan kesadaran akan nilai-nilai kemanusiaan yang meiliki tekanan pokok pada pemahaman mengenai beberapa nilainilai kemanusiaan. [11]

Adapun pengertian universal menurut KBBI adalah umum, atau berlaku untuk semua orang atau untuk seluruh dunia, bersifat (melingkupi) seluruh dunia. 'Universal' ketika diintegrasikan dengan 'humanisme' atau kemanusiaan, maka ia memiliki makna bahwa konsep humanisme atau kemanusiaan adalah konsep yang berlaku secara universal, dimiliki oleh setiap manusia tanpa membedakan apakah manusia tersebut berkulit hitam, berkulit putih, baragama Islam atau beragama Kristen, berkebudayaan suku Jawa ataukah suku Dayak, apakah ia orang Tionghoa atau orang Amerika. Inilah yang kemudian menjadi semangat pendirian, cita-cita dan politik Kebudayaan Nasional, atau pencarian identitas nasional, sebagai bentuk perjuangan untuk mempertahankan dan mengembangkan martabat sebagai bangsa Indonesia di tengah masyarakat bangsabangsa, sebagaimana yang diungkapkan pada Manifesto Kebudayaan (Manikebu).

Penelitian ini bertujuan untuk mengisi kekosongan yang terkait dengan penggalian nilai-nilai simbolik semangat zaman secara historis. Landasan ideologis digali mulai masa Teguh pada masa mudanya hingga masa dia mulai menemukan bentuk, gaya, dan pola produksi yang konsisten di tahun '70-'80-an. Tiga rumusan masalah penelitian disusun sebagai berikut: Bagaimanakah makna primer yang membentuk dunia motif artistik pada Komik "Sandhora" (1970) karya Teguh Santosa. Bagaimanakah makna sekunder yang membentuk dunia gambar Komik "Sandhora" (1970) karya Teguh Santosa. Terakhir, bagaimanakah makna intrinsik yang membentuk dunia nilai simbolik Komik "Sandhora" (1970) karya Teguh Santosa.

\section{METODE PENELITIAN}

Penelitian ini mengkaji Komik "Sandhora" yang dikerjakan oleh Teguh Santosa pada tahun 1970. Pendekatan yang dipergunakan penelitian sejarah, yang tidak lain bersifat kualitatif. Madjid dan Wahyudi memaparkan alur metodologi sejarah sebagai sebuah prosedur, yang terdiri dari : 1) Heuristik; 2) Kritik sumber; 3) Interpretasi; dan 4) Historiografi. Heuristik berarti adalah mengumpulkan sumber. Sumber yang dimaksud adalah sumber sejarah atau dapat juga disebut sebagai fakta sejarah: catatan, kesaksian dan fakta-fakta lain yang dapat memberikan penggambaran tentang sebuah peristiwa yang menyangkut kehidupan manusia. Sumber-sumber ini didapatkan dari studi kepustakaan, wawancara, dan juga dokumentasi. Fakta sejarah bedasarkan bentuknya dibagi menjadi 4, yakni : 1) Artefact; 2) Sosiofact; 3) Mentifact; dan 4) Ecofact. [12] 
Triangulasi data dijalankan melalui sumber atau pengujian melalui serangkaian kritik, baik yang bersifat intern maupun ekstern. Kritik intenal dilakukan untuk menilai kelayakan atau kredibilitas sumber, dan mengacu kepada kemampuan sumber untuk mengungkap kebenaran. Kritik eksternal dilakukan untuk mengetahui sejauh mana keabsahan dan autensitas sumber. Kritik ekstern dilakukan dengan jalan melakukan pengecekan mengenai tanggal penerbitan dokumen, memastikan bahwa sumber tersebut asli atau salinan, dan lain sebagainya. Dalam kajian ini, kritik sumber dilakukan secara fleksibel, baik setelah sumber didapatkan ataupun setelah proses analisis.

Pendekatan teori ikonografi dan ikonologi dipergunakan sebagai pendekatan dalam menganalisis data yang telah diperoleh. Kajian Ikonografi merupakan cabang dari sejarah seni yang menaruh perhatian terhadap pokok bahasan (subject matter) atau makna (meaning) dari karya seni rupa, dimana kedua hal tersebut merupakan lawan dari bentuk seni (form) [13]. Dalam kajian Ikonografi dan Ikonologi, analisis data dilakukan dalam tiga tahap, yakni : 1) tahap deskripsi pra-ikonografis; 2) tahap analisis ikonografis dan 3) tahap interpretasi ikonologis. Ketiga tahapan tersebut memiliki pertautan yang bersifat prerequisite atau prasyarat dari tahapan satu terhadap tahapan selanjutnya. Adapun historiografi (penulisan sejarah) dapat juga dipahami sebagai cara penulisan, pemaparan, atau pelaporan hasil penelitian sejarah yang telah dilakukan [14], sehingga laporan hasil penelitian atau artikel ini tidak lain adalah historiografi itu sendiri. Prosedur tersebut dapat dilihat pada gambar 1.

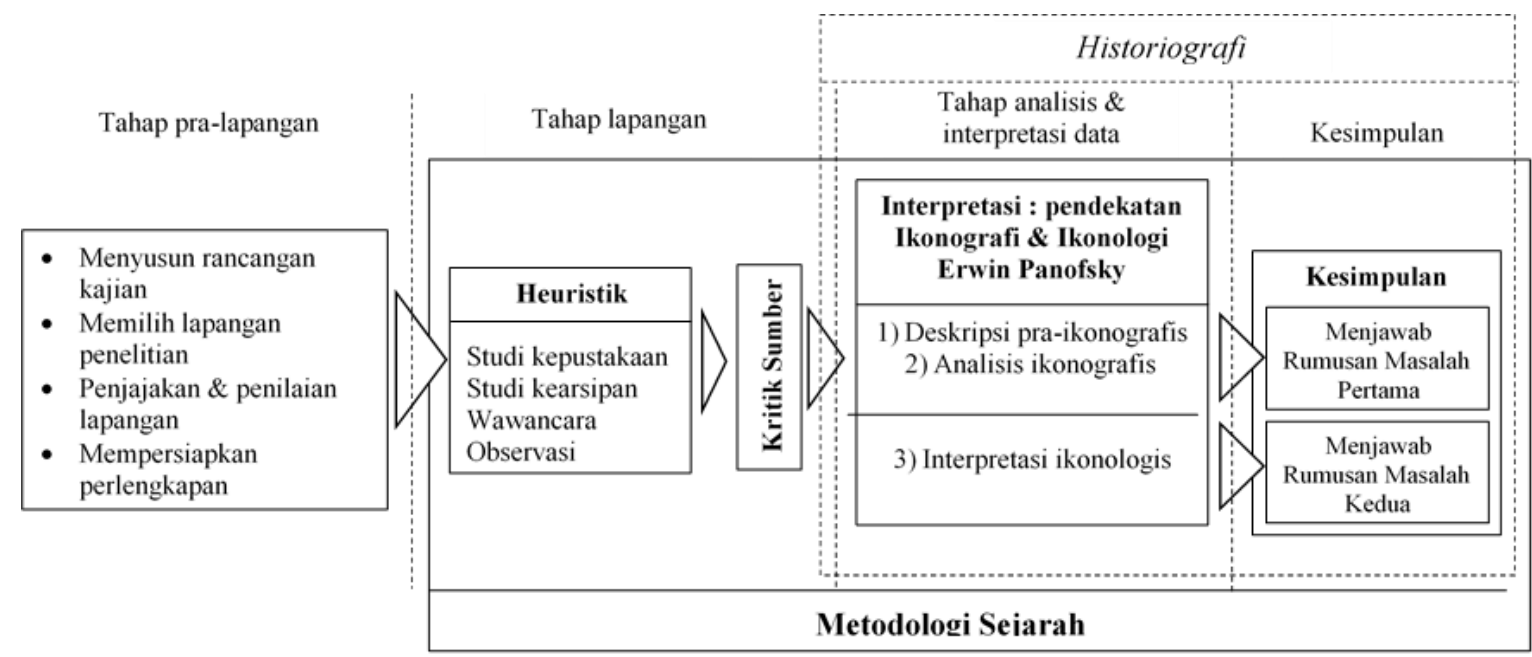

Gambar 1. Bagan alir kajian Ikonografi dan Ikonologi Komik "Sandhora" (1970) karya Teguh Santosa. [Sumber : diolah dari Moleong, 2013; dan Madjid \& Wahyudi, 2014] [15] [12]

Tahap pra-ikonografi adalah tahap yang pertama, berisi tanggapan awal pada aspek tekstual yang ada dalam batasan motif artistik. Pada tahap ini, baik unsur intrinsik dan visual komik dianalisis dengan tujuan untuk menemukan nilai primer komik. Dalam tahap kedua, yaitu analisis ikonografi merupakan tahap untuk mengidentifikasi makna sekunder. Proses ini merupakan pembacaan arti dari aspek-aspek tekstual sebelumnya yang pada tahap ini dihubungkan dengan tema dan konsep. Dari kedua tahap tersebut, 
yakni tahap deskripsi pra-ikonografis dan analisis ikonografis, akan didapatkan penjelasan yang menjawab rumusan masalah penelitian pertama dan kedua.

Tahap yang ketiga adalah tahap interpretasi ikonologis, merupakan tahapan yang paling esensial untuk memahami makna intrinsik atau isi dari sebuah karya seni. Setelah melalui pemahaman lewat deskripsi pra ikonografi dan analisis ikonografi, maka dalam tahap ini dibutuhkan kemampuan mental yang disebut dengan intuisi sintesis dalam memahami simbol. Intuisi sintesis menyangkut tendensi esensial pemikiran psikologi personal dan weltanschauung (pandangan hidup) pencipta karya [13]. Dari tahap yang ketiga ini akan didapatkan sebuah penjelasan mengenai nilai-nilai simbolik yang diungkapkan dalam Komik "Sandhora" (1970) karya Teguh Santosa, atau dengan kata lain menjawab rumusan masalah yang kedua dari kajian ini. Ketiga tahap tersebut merupakan alat interpretasi. Untuk mencapai ketajaman analisis, diperlukan prinsip korektif interpretasi yang berfungsi sebagai kerangka konfirmasi, seperti yang dijabarkan pada tabel 1 dan 2 berikut ini.

Tabel 1. Tahapan, objek interpretasi dan aksi interpretasi dalam kajian ikonologi dan ikonografi [Sumber: Panofsky, 1955] [13].

\begin{tabular}{|l|l|l|}
\hline No. & \multicolumn{1}{|c|}{ Objek Interpretasi } & \multicolumn{1}{|c|}{ Aksi Interpretasi } \\
\hline I & $\begin{array}{l}\text { Makna primer atau natural subject matter - (A) } \\
\text { faktual, dan (B) ekspresional - yang membentuk } \\
\text { dunia motif artistik. }\end{array}$ & $\begin{array}{l}\text { Deskripsi pra-ikonografis } \\
\text { (dan analisis pseudo- } \\
\text { formal). }\end{array}$ \\
\hline II & $\begin{array}{l}\text { Makna sekunder atau conventional subject matter, } \\
\text { yang membentuk dunia gambar, cerita, dan alegori. }\end{array}$ & Analisis ikonografis \\
\hline III & $\begin{array}{l}\text { Makna intrinsik atau isi (content), yang membentuk } \\
\text { dunia nilai simbolik. }\end{array}$ & Interpretasi ikonologis \\
\hline
\end{tabular}

Tabel 2. Alat interpretasi dan prinsip korektif interpretasi dalam kajian ikonografi dan ikonologi [Sumber: Panofsky, 1955] [13].

\begin{tabular}{|c|c|}
\hline Alat Interpretasi & Prinsip Korektif Interpretasi \\
\hline $\begin{array}{l}\text { Pengalaman praktis (rasa } \\
\text { familiar/akrab dengan suatu objek } \\
\text { atau peristiwa. }\end{array}$ & $\begin{array}{l}\text { Sejarah gaya (wawasan atau pengetahuan } \\
\text { yang mendalam tentang gaya) }\end{array}$ \\
\hline $\begin{array}{l}\text { Pengetahuan tentang sumber literer } \\
\text { (rasa familiar/akrab terhadap tema } \\
\text { dan konsep). }\end{array}$ & $\begin{array}{l}\text { Sejarah tipe (wawasan tema dan konsep } \\
\text { spesifik yang terekspresikan melalui objek dan } \\
\text { peristiwa. }\end{array}$ \\
\hline $\begin{array}{l}\text { Intuisi sintetis (rasa familiar dengan } \\
\text { tendensi-tendensi esensial dari } \\
\text { pikiran manusia), yang dikondisikan } \\
\text { oleh psikologi personal dan } \\
\text { "Weltanschauung" (pandangan } \\
\text { hidup). }\end{array}$ & $\begin{array}{l}\text { Sejarah gejala kultural (cultural symptoms), } \\
\text { wawasan yang mempengaruhi sikap seniman } \\
\text { yang tumbuh dengan kondisi sejarah tertentu, } \\
\text { dorongan-dorongan, dan tendensi yang } \\
\text { terekspresikan dalam tema dan konsep karya } \\
\text { seni. }\end{array}$ \\
\hline
\end{tabular}




\section{HASIL DAN PEMBAHASAN}

\subsection{Deskripsi Pra-Ikonografi}

Pada bagian pembahasan dipaparkan hasil atau temuan terkait dengan pertanyaan penelitian yang pertama yaitu makna primer yang membentuk dunia motif artistik pada Komik "Sandhora" (1970) karya Teguh Santosa. Penelitian ini menemukan bahwa makna primer yang membentuk dunia motif artistik pada Komik "Sandhora" ialah menceritakan tentang kisah cinta antara dua tokoh utama yakni Sandhora dan Mat Pelor, yang didalam perjalanannya penuh dengan konflik dan ketegangan yang muncul karena gesekan/benturan dengan para tokoh antagonis.

Aspek faktual tersebut terbentuk melalui relasi antar elemen komik berupa aspek unsur intrinsik dan aspek visual. Analisis unsur intrisik meliputi tematis, alur, penokohan dan perwatakan, narasi tekstual dan setting. Sementara itu, unsur visual meliputi gaya ketepatan obyektif, teknik representasi visual (goresan garis, arsiran pengeblokan), genre, dan sound lettering. Berikut ini adalah penyajian hasil analisis unsur visual komik dan unsur intrinsik dilakukan pada prosa fiksi yang ada dalam Komik "Sandhora" yaitu terdiri dari tema, alur, penokohan dan perwatakan, narasi tekstual dan setting (unsur intrinsik) dan gaya ketepatan obyektif, teknik representasi visual (goresan garis, arsiran, blocking), genre, dan sound lettering (unsur visual).

Secara tematis, Komik "Sandhora" (1970) karya Teguh Santosa ini adalah komik yang menceritakan tentang kisah cinta antara dua tokoh utama yakni Sandhora dan Mat pelor. Tema berasal dari bahasa Latin 'theme' yang berarti 'pokok pikiran' [16]. Adapun yang dimaksud sebagai tema dalam konteks prosa fiksi menurut Scharbach berasal dari bahasa Latin yang berarti 'tempat meletakkan suatu perangkat', karena tema adalah ide yang mendasari suatu cerita sehingga berperanan juga sebagai pangkal tolak pengarang dalam memaparkan karya fiksi yang diciptakannya [17]. Tema menurut Scharbach adalah kaitan antara makna dan tujuan, sehingga untuk memahami tema, seorang pembaca harus memahami unsur-unsur signifikan yang membentuk cerita, dan menyimpulkan makna (primer) yang dikandungnya, sebagaimana yang telah dilakukan pada tahap deskripsi pra-ikonogarfis.

Terkait dengan analisis alur, komik ini mengisahkan perjalanan hidup yang penuh konflik dan ketegangan karena gesekan/benturan dengan para tokoh antagonis. Komik ini terdiri dari 10 jilid ini dan memiliki alur yang cukup kompleks yaitu terdiri dari 1) Exposition (jilid 1), 2) Inciting force (jilid 2), 3) Pengembangan cerita/dinamisasi (Jilid 39); hingga pada 4) Climax; 5) Falling action; dan 6) Conclusion, dimana tiga tahap terakhir terjadi pada jilid 10. Secara ringkas visualisasi alur cerita Komik "Sandhora" digambarkan pada gambar 2. 


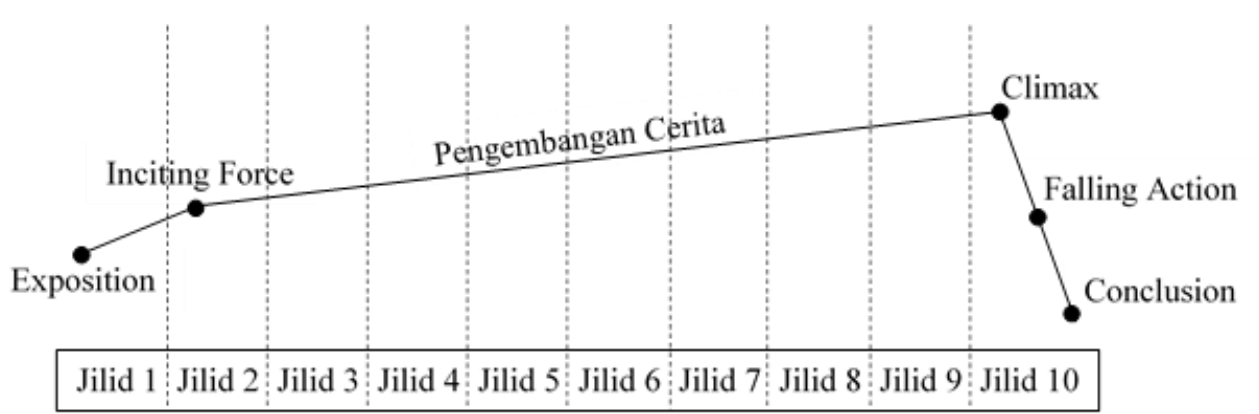

Gambar 2. Tahapan plot Komik "Sandhora" secara garis besar.

[Sumber: Aditya \& Daniel]

Dari identifikasi penokohan dan perwatakan didapatkan 10 tokoh protagonis dan 13 tokoh antagonis. Kedua puluh tiga tokoh tersebut merupakan tokoh yang benar-benar menampakkan wajahnya dan diketahui dengan jelas namanya. Beradasarkan peranan dan keseringan pemunculan tokoh dalam komik, terdapat dua tokoh utama yaitu Sandhora dan Mat Pelor. Disamping itu, judul komik juga menegaskan tokoh utama komik ini tidak lain adalah Sandhora sendiri. Mat Pelor merupakan tokoh yang memiliki hubungan penting dengan dengan tokoh utama. Sementara itu, 21 tokoh sisanya adalah tokoh pendukung. Tokoh lain bernama Dul Rasjid, Marcos Varga, dan Miguel dapat dipandang sebagai tokoh pendukung, namun memiliki complex character.

Bertitik tolak pada narasi tekstual pada caption, Teguh Santosa memaparkan cerita dengan mengambil titik pandang narrator omniscient: pengisah yang berfungsi sebagai pelaku cerita. Teguh sebagai komikus tahu secara pasti dan cukup mendetail suasana batin dan pikiran yang dialami oleh Sandhora, melalui sebuah tuturan dalam caption pada halaman 56 : "Sebenarnya Sandhora lebih senang mendengar Mat Pelor berbicara tentang cinta, tetapi naluri kewanitaannya mengekang keinginan agar Mat Pelor berbicara soal itu! Sandhora mulai bisa menilai bagaimana Mat Pelor ini, bukannya ia seorang yang berpengetahuan rendah lebih-lebih dalam menilai masalah hidup yang seba pelik ini!".
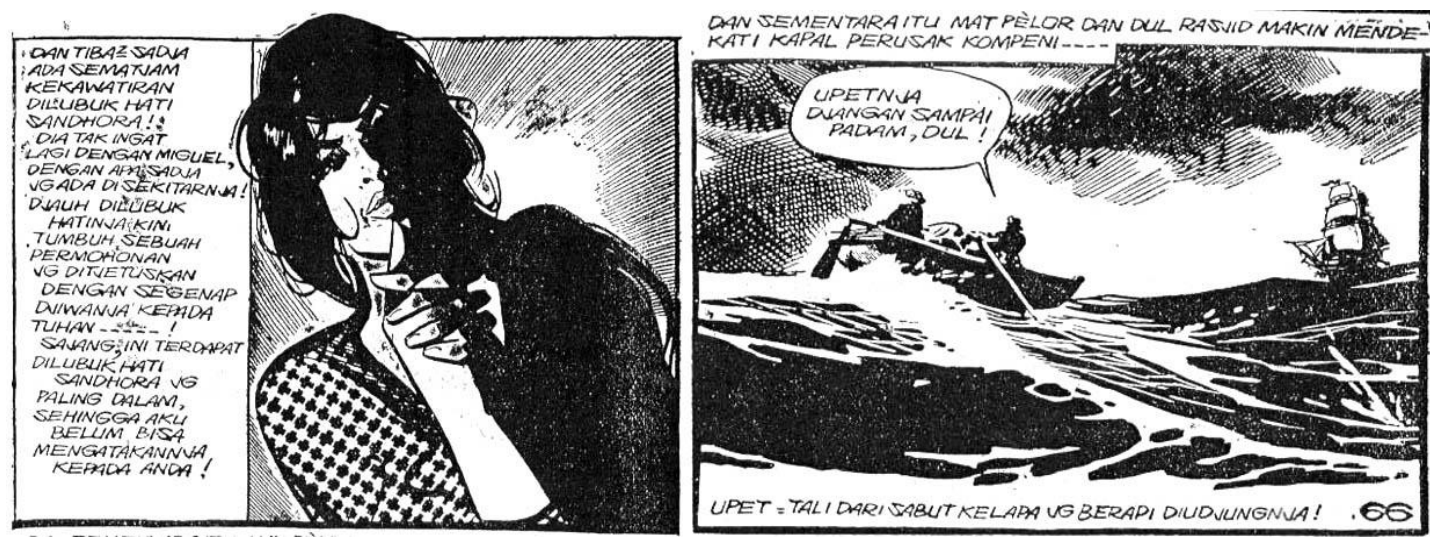

Gambar 3. Komikus memposisikan diri sebagai pelaku ketiga yang tidak terlibat secara langsung dalam keseluruhan satuan dan jalinan cerita. [Sumber : Santoso, 1970] [7]

Teguh juga memposisikan diri sebagai pelaku ketiga yang tidak terlibat secara langsung dalam keseluruhan satuan dan jalinan cerita. Pada gambar 3 (komik halaman 66) Teguh menggunakan kata aku untuk menggantikan dirinya sebagai pelaku ketiga 
melalui penuturan dalam caption "...Sayang, ini terdapat dalam lubuk hati Sandhora yang paling dalam, sehingga aku belum bisa mengatakannya kepada anda!". Di sini Teguh yang serba tahu seolah-olah merahasiakan apa yang sudah semestinya ia tahu, ia membuat suatu teka-teki yang dilemparkan kepada pembaca, yang ia sebut sebagai "anda" dalam tuturan itu.

Setting komik ini terdiri dari dua jenis, yaitu fisikal dan psikologis. Setting yang bersifat fisikal adalah setting yang berhubungan dengan tempat, misalnya kota Jakarta, daerah pedesaan, pasar, sekolah, dan lain-lain, serta benda-benda. Setting fisikal ini bermula di kota Surabaya pada tahun 1830, dan berakhir di Teluk Amurang, Menado, pada akhir tahun 1831. Kisah ini berlangsung hampir selama satu tahun, bertepatan dengan berakhirnya Perang Jawa (Perang Diponegoro), dan ditengah berkecamuknya Perang Paderi di Sumatera. Setting psikologis adalah setting berupa lingkungan tertentu yang mampu menuansakan suatu makna serta mampu mengajuk emosi pembaca, atau dengan kata lain mengekspresikan suatu makna tertentu (makna ekspresional). Terkait dengan setting psikologis, setelah dilakukan deskripsi pra-ikonografis, ada beberapa kata kunci yang sering muncul, diantaranya ketegangan, pertarungan antara hidup dan mati, kelicikan, kekesatriaan, dan harapan.

Secara umum komik ini menampakkan pendekatan ketepatan obyektif. Gaya ketepatan obyektif ialah ketika sebuah bentuk karya seni memiliki hubungan dekat dengan fenomena visual yang diimitasi [18]. Karya seni dengan gaya ini memiliki kemiripan secara kualitatif dengan objek yang diacunya (referen), atau dengan kata lain bersifat 'ikonis'. Pendekatan ini juga nampak pada komikus dengan karya komik yang lain yang sezaman, semisal Ganes TH dalam karyanya Si Buta dari Goa Hantu (1968), dan Hans Jaladara dalam karyanya Panji Tengkorak yang terbit pertama kali tahun 1967. Meskipun sama-sama menggunakan pendekatan yang sama, nampak bagaimana Teguh memiliki kemampuan teknis yang lebih akurat dalam hal mewujudkan obyek gambar dengan lebih obyektif (memiliki kesamaan kualiatif yang lebih tinggi dengan obyek yang diacunya), begitu juga dalam hal kompleksitas elemen (detail) dan komposisi.

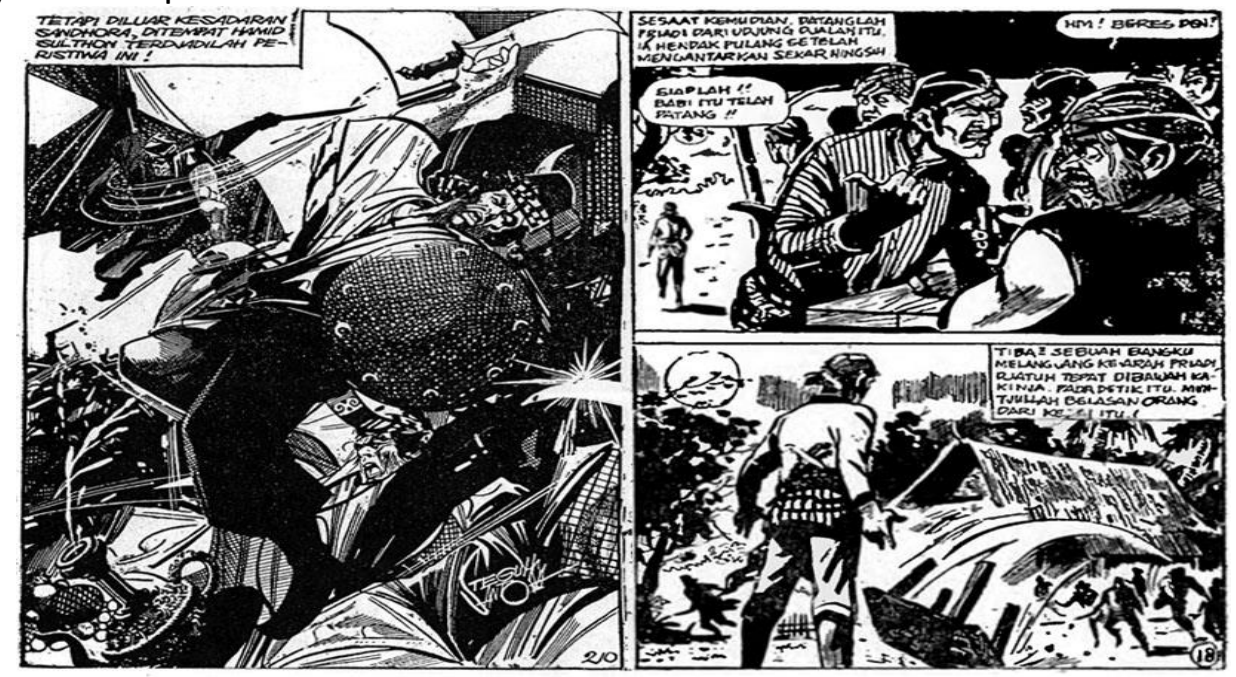

Gambar 4. Gaya ketepatan obyektif Teguh Santosa (Kiri), dan pendekatan yang sama oleh Ganes TH dalam Si Buta dari Goa Hantu (Kanan). [Sumber : Santosa, 1970; TH, 1968] [7] [19] 
Dalam hal teknik, gambar Teguh menunjukkan keluwesan goresan garis, baik dalam goresan garis lurus, maupun kurva, dan juga nampak pada arsiran yang ia buat. Hal ini menyebabkan berbagai pose manusia menjadi lebih natural dan proporsional. Adapun gaya yang lebih personal (khas) dari gaya gambar Teguh Santosa adalah penggunaan blok hitam. Tehnik ini dilakukan secara "tidak sengaja" ketika sebuah bidang yang awalnya terisi dengan arsiran garis tipis-tipis, tiba-tiba berubah menjadi blok hitam setelah dicetak dengan menggunakan mesin cetak [20]. Teknik blok hitam, arsiran, dan cahaya kontras semakin menguat ketika dipengaruhi oleh gaya gambar komikus Inggris Frank Bellamy. Mengenai pengaruh Frank Bellamy, Bambang Priyadi (Eroest BP), asisten Teguh sampai pada tahun 1982, dalam pernyataannya yang ditujukan untuk mengapresiasi komik "The Women of Galba" (Serial "Garth", dipublikasikan 27 Desember 1972 - 10 April 1973) pada tanggal 25 Maret 2016 mengatakan bahwa :

"...Saya jadi teringat Alm Teguh Santosa yang tak kurang berusaha meresapi dan menerapkan jurus-jurus dahsyat ini (teknik blok hitam) dalam setiap goresannya, tak semata-mata mengadopsinya. Teguh Santosa masih berupaya melarutkan dan memfusikan pengalaman tersebut dalam pengalaman pribadinya. Saya pun tak ragu memposisikan Frank Bellamy jadi guru imajiner saya sambil memadukan jurus-jurus yang kudapat dari guru-guru yang lain...". [20]

Genre Komik "Sandhora" adalah "Roman Sejarah". Ruttkowski dan Reichmann mengemukakan bahwa sebagai salah satu karya sastra epik panjang, roman berisi paparan cerita yang panjang dan terdiri dari beberapa bab, dimana antara bab satu dengan yang lain saling berhubungan [21]. Biasanya roman bercerita tentang suatu tokoh dari lahir sampai mati. Prinsip dasar dari roman petualangan menurut Bittner adalah bahwa tokoh utama berangkat dari dunianya sehari-hari ke sebuah dunia asing dan berbahaya, di mana dia mempunyai bermacam-macam masalah dan tugas yang harus diatasi di bawah bayang-bayang bahaya maut [22]. Tujuan dari perjalanannya biasanya adalah pertolongan atau penyelamatan seseorang atau dunianya sendiri. Di dalam aturan roman petualangan diceritakan dari pandangan tokoh utama yang mempresentasikan kebaikan dan sering melawan kejahatan atau kekuasaan yang suram dan akhirnya menang. Apa yang disebut oleh Bittner sebagai ciri-ciri roman petualangan di atas hampir seluruhnya nampak dalam Komik "Sandhora" (1970). Komik ini memunculkan pelukisan secara riil terhadap kejadian yang berorientasi pada melimpahnya tingkah laku tokoh utama. Secara cepat situasi-situasi dan setting cerita dalam komik berubah-ubah. Tehnik ini memberi kesan alur cerita menjadi peristiwaperistiwa fantastis dan sekaligus menimbulkan ketegangan. Namun setiap adegan dan peristiwa fiktif yang berlangsung dalam komik ini ditempatkan dalam setting waktu, dan tempat yang benar-benar ada, serta peristiwa yang benar-benar telah terjadi di masa lampau dan berusaha menghubungkannya (Perang Jawa, dan Perang Paderi). Sehingga dapat dikatakan bahwa genre komik ini tergolong hybrid, yakni roman petualangan dan roman sejarah, atau roman petualangan-sejarah. Genre yang sama nampak pada karya komik "Taufan" (1973) karya Ganes TH dengan setting waktu masa revolusi kemerdekaan Indonesia, atau "Njai Dasima" (1969) karya Yus Chandra dengan setting tahun 1820-an di Jakarta (Betawi). 
Teks sebagai sound lettering beberapa kali juga muncul dalam Komik "Sandhora" (1970), sebagai ekspresi dari ucapan yang dikeluarkan oleh obyek (alam benda) dalam dunia komik, semisal "TOK TOK TOK!" untuk suara pintu, dan lain sebagainya. Sound lettering ini merupakan "tradisi" dalam komik, dan hampir dapat ditemui keberadaanya hampir pada setiap komik yang pernah dibuat. Dalam Komik "Sandhora" secara umum Teguh menggambarkannya rata-rata 2 panel pada setiap halamannya, namun tidak pernah lebih dari 3 panel. Kebanyakan panel menggunakan garis batas yang tegas, sebagian tidak menggunakan garis/batas yang jelas, serta beberapa panel "tertembus" oleh gambar ilustrasi yang menyeruak keluar. Tidak ada yang khusus dalam Komik "Sandhora" (1970) dalam hal panel, segala sesuatunya sesuai dengan tradisi di dalam komik, sehingga pada elemen gutter juga ada sebagaimana mestinya. Adapun elemen balon, dalam Komik "Sandhora" terdiri dari beberapa bentuk, yakni balon ucapan sebagai medium teks yang berupa ucapan atau dialog, dan balon pikiran yang berbentuk seperti awan sebagai medium teks berupa alam pikiran dalam benak tokoh. Caption dalam Komik "Sandhora" berfungsi sebagai medium teks yang menjelaskan mengenai setting waktu, tempat, dan peristiwa, menjelaskan identitas atau jatidiri seorang tokoh dalam komik, memperjelas/mendeskripsikan adegan yang sedang berlangsung. Disamping itu caption juga berfungsi untuk menjelaskan sudut pandang komikus yang telah dijelaskan pada bahasan elemen sudut pandang. Adapun penggambaran ekpresional dalam komik ini mengungkapkan sebuah kisah cinta dan petualangan yang penuh dengan ketegangan, pertarungan antara hidup dan mati, kelicikan, kekesatriaan, dan harapan, yang diekspresikan melalui penokohan dan perwatakan, alur, sudut pandang, setting waktu, tempat, dan peristiwa, serta tentunya gaya gambar personal Teguh, berupa teknik blok hitam yang turut mengintensifkan ekspresi ketegangan dalam komik ini.

\subsection{Analisis Ikonografis}

Pada bagian ini diketengahkan hasil sebagai jawaban dari pertanyaan penelitian kedua yaitu bagaimanakah makna Sekunder yang membentuk dunia gambar dari Komik "Sandhora" (1970) karya Teguh Santosa. Untuk menjawab rumusan masalah ini, analisis ikonografis dilakukan. Dalam tahap ini diperlukan pengamatan dengan melihat hubungan bentuk-bentuk dan tema serta konsepnya dalam kebiasaan pengalaman praktis. Di samping itu juga dibutuhkan kebiasaan pengalaman melihat hubungan konsep dan tema dari karya seni yang diperoleh dari berbagai imaji, sumber literer, dan alegori [13].

Penelitian ini menemukan bahwa dari makna sekunder Komik "Sandhora" adalah tentang kemanusiaan: cinta yang tulus dan suci akan menemukan jalannya untuk bersatu, dan selama itu pula kebiadaban, kelicikan, dan keserakahan akan terus membayang-bayangi, dengan menempatkan cinta kasih dalam perjuangan antara hidup dan mati. Dan tidak ada cara lain, selain tetap berpijak pada kebenaran, ajaran kasih sayang, religiusitas, dan nilai-nilai kemanusiaan. Tema ini juga terekespresikan dalam sikap Teguh dengan menyajikan kepada pembaca suatu pemahaman bahwa agama sejatinya mengedepankan cinta kasih terhadap sesama manusia, menghargai perbedaan, serta toleransi, atau dengan perkataan lain semangat pluralisme dan 
multikulturalisme. Tema dan sikap yang dibangun oleh Teguh dalam komik ini menunjukkan komitmen yang kuat terhadap paradigma estetik Humanisme Universal, yang populer pada paruh kedua 1960-an hingga tahun 1980-an.

Mengenai sikap komikus, ialah sikap terhadap pokok-pokok pikiran yang ditampilkannya. Sikap adalah pernyataan evaluatif terhadap objek, orang atau peristiwa. Hal ini mencerminkan perasaan seseorang terhadap sesuatu [23]. Sikap mempunyai tiga komponen utama: 1) kesadaran; 2) perasaan, dan 3) perilaku [24]. Mengenai sikap pengarang/komikus dalam komik dapat dilihat dari bagaimana ia mengungkapkan perasaannya (pernyataan evaluatif, menilai atau mengukur) terhadap tokoh, peristiwa, atau objek dalam komik, yang tentunya sangat terkait erat dengan unsur sudut pandang (point of view), dan bagaimana komikus mengilustrasikan peristiwa dan objek melalui gambar dalam panel. Pada halaman 31, melalui teks dalam caption pada panel pertama dan kedua: "Dan pada suatu saat mereka mendapat tantangan dari Samodra Hindia"; "Pada saat-saat begini mereka merasakan betapa ketjilnya manusia ini apabila dibandingkan dengan kedahsjatan alam! Badai mengamuk mengombang-ambingkan kapal mereka bagai sabut kelapa! Puntjak ketakutan mereka telah menggerakkan bibir mereka untuk menjebut nama Tuhan!". Secara eksplisit Teguh sebagai pengarang mengungkapkan tentang manusia yang kecil, remeh di mata alam dan Tuhan.

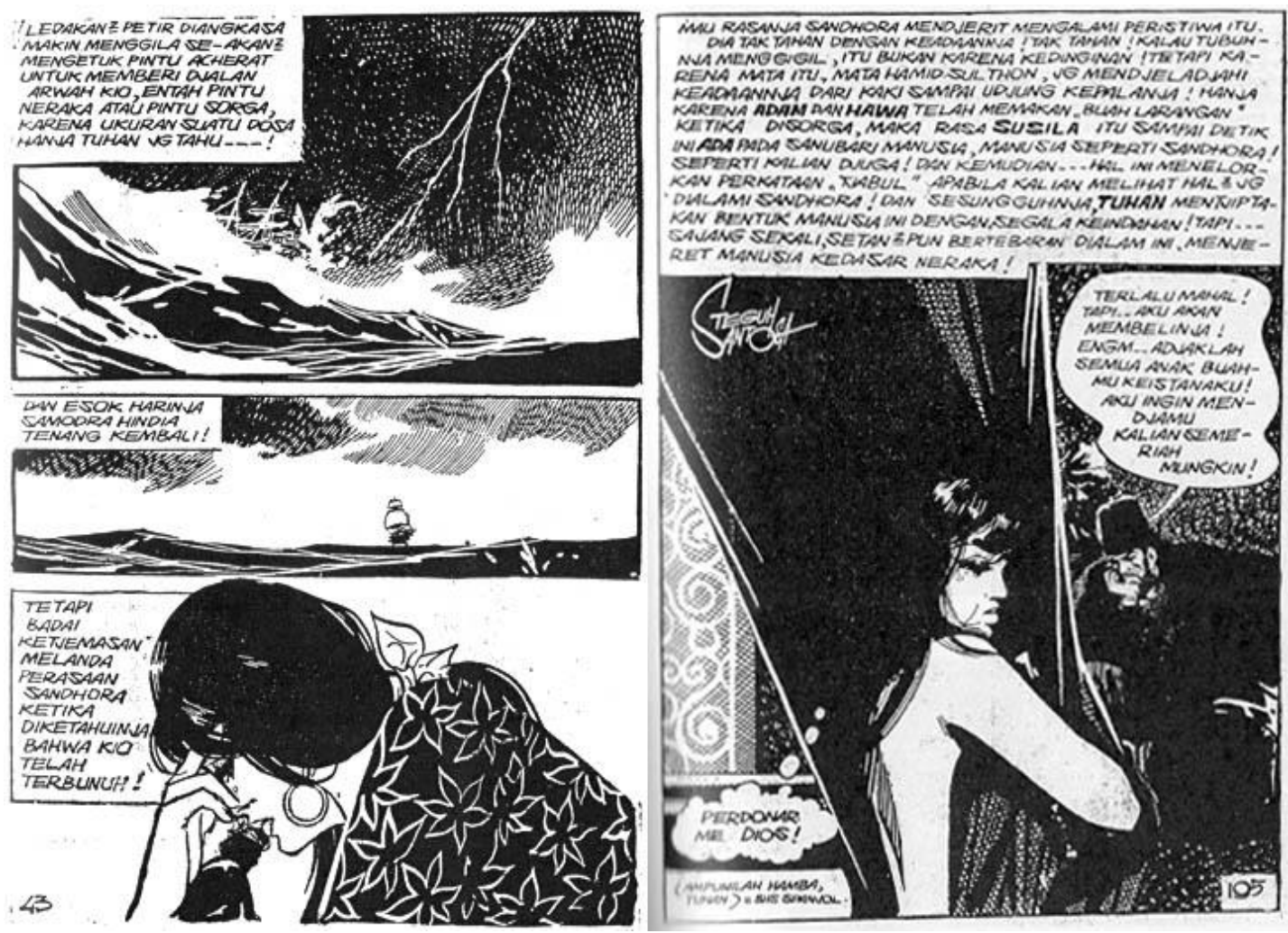

Gambar 5. Pada caption halaman 43 panel pertama, nampak anjuran untuk tidak menghakimi seseorang, dan pada halaman 105, Teguh melakukan upaya reflektif, berempati, sembari melaknat kecabulan Hamid Sulthon. [Sumber : Santoso, 1970] [7] 
Pada komik halaman 105 (gambar 5), dalam satuan peristiwa ketika Sandhora 'dizalimi' Hamid Sulthon di pulaunya, melalui teks dalam caption Teguh menyatakan demikian : “...Hanja karena Adam dan Hawa telah memakan buah larangan ketika di sorga, maka rasa susila itu sampai detik ini ada pada sanubari manusia, manusia seperti Sandhora! Seperti kalian juga! Dan kemudian ...hal ini menelorkan perkataan 'tjabul' apabila kalian melihat hal-hal yang dialami Sandhora! Dan sesungguhnya, Tuhan mentjiptakan bentuk manusia ini dengan segala keindahan! Tapi... sajang sekali, setan-setan pun bertebaran di alam ini, menjeret manusia ke dasar neraka". Dalam caption tersebut nampak Teguh melakukan upaya-upaya reflektif terhadap satuan peristiwa yang telah ia paparkan, ia mengajak pembaca untuk kembali menafsirkan ulang makna 'dosa' dan mengajak pembaca untuk ikut merasakan atau berempati terhadap kemalangan Sandhora, sembari melaknat kecabulan Hamid Sulthon.

Pernyataan evaluatif Teguh mengenai manusia yang saling membunuh satu sama lain juga dijumpai pada halaman 257, ia mengungkapkan demikian : “...Betapa ngeri, sadis, dan kedjam peperangan itu kendati begitu banjak orang diantara berdjuta-djuta manusia di djagad fana ini jang selalu haus akan perang! Kedjangkitan penjakit, histeris perang. Apabila dalam seratus tahun tak ada perang di dunia ini! Menjimpang sedikit tentang perang, marilah kita ikuti pertarungan tadi..., dan...inilah mereka!". Disini dapat dijumpai bagaimana Teguh berkomentar, menyatakan sikap atas peperangan yang merupakan subject matter yang ia hadirkan dalam satuan peristiwa ini. Secara eksplisit teguh menyatakan sikap anti-perangnya melalui kata-kata dalam caption, pun secara implisit juga nampak pada gambar ilustrasi dalam panel yang mengekpresikan kengerian dalam peperangan, sosok manusia yang mengamuk dan kesakitan, sabetan senjata tajam, percikan darah, serta nuansa psikologis yang dibangun melalui dunia gambar begitu suram, atau gelap dengan blok-blok hitam dan arsiran. Disamping melaknat kebejadan moral dan mengutuk kekerasan, ekspresi sikap yang cukup unik dari Teguh dalam komik ini ialah bagaimana ia menampakkan diri sebagai seorang yang pluralis melalui karyanya. Pada halaman 278 dan beberapa halaman setelahnya, nampak bagaimana ia menampakkan sikap semacam itu, melalui caption ia mengatakan demikian: "...peristiwa semalam telah memberi pengertian pada Mat Pelor bahwa paham yang berbedalah jang membentuk tembok pemisah! 'Tembok' jang didirikan oleh sang datuk! Tetapi tjinta lebih hebat dan mempunyai nafas tersendiri! Tjinta Markam dan Zahra tak lekang oleh keadaan, dan tembok itu runtuh...bersama kematian sang datuk!".

Dalam caption tersebut nampak bagaimana Teguh menyampaikan tentang cinta yang kerapkali terberai oleh perbedaan ideologis, dalam konteks satuan peristiwa tersebut ialah Markam yang merupakan kaum Paderi dan kakek Zahra (Datuk Badrowi) merupakan kaum adat, dimana pada masa perang Paderi keduanya berperang. Namun Teguh mengungkapkan disini, bahwa cinta yang tulus dan murni adalah bersifat suci, sehingga ia akan menemukan jalannya untuk bersatu. Nampak bagaimana Teguh memberikan pernyataan evaluatif terhadap konflik-konflik agama yang sebenarnya kontradiktif dengan ajaran agama itu sendiri, yang mengajarkan cinta dan kasih sayang. Hal yang serupa juga nampak pada gambar 6 yaitu halaman 452 dan 453. 
Dalam satuan adegan tersebut, terjadi pernikahan antara Sandhora dengan Mat Pelor yang berbeda agama, dan dilangsungkan oleh Padri Jose Agualnido. Teguh mengungkapkan pandangannya mengenai peristiwa ini melalui teks dalam caption pada halaman 452, ia menyatakan: "Saat-saat bahagia jang direguk dua asmarawan terpantul dari sikap-sikap menerima setelah upatjara pernikahan selesai! Djuga sampai beberapa hari berikutnja! terlupa sudah saat-saat bersama jang pernah mereka alami! Dihirupnja udara kehidupan ini dengan nada-nada harmonis untuk mengembangkan hasrat hidup".
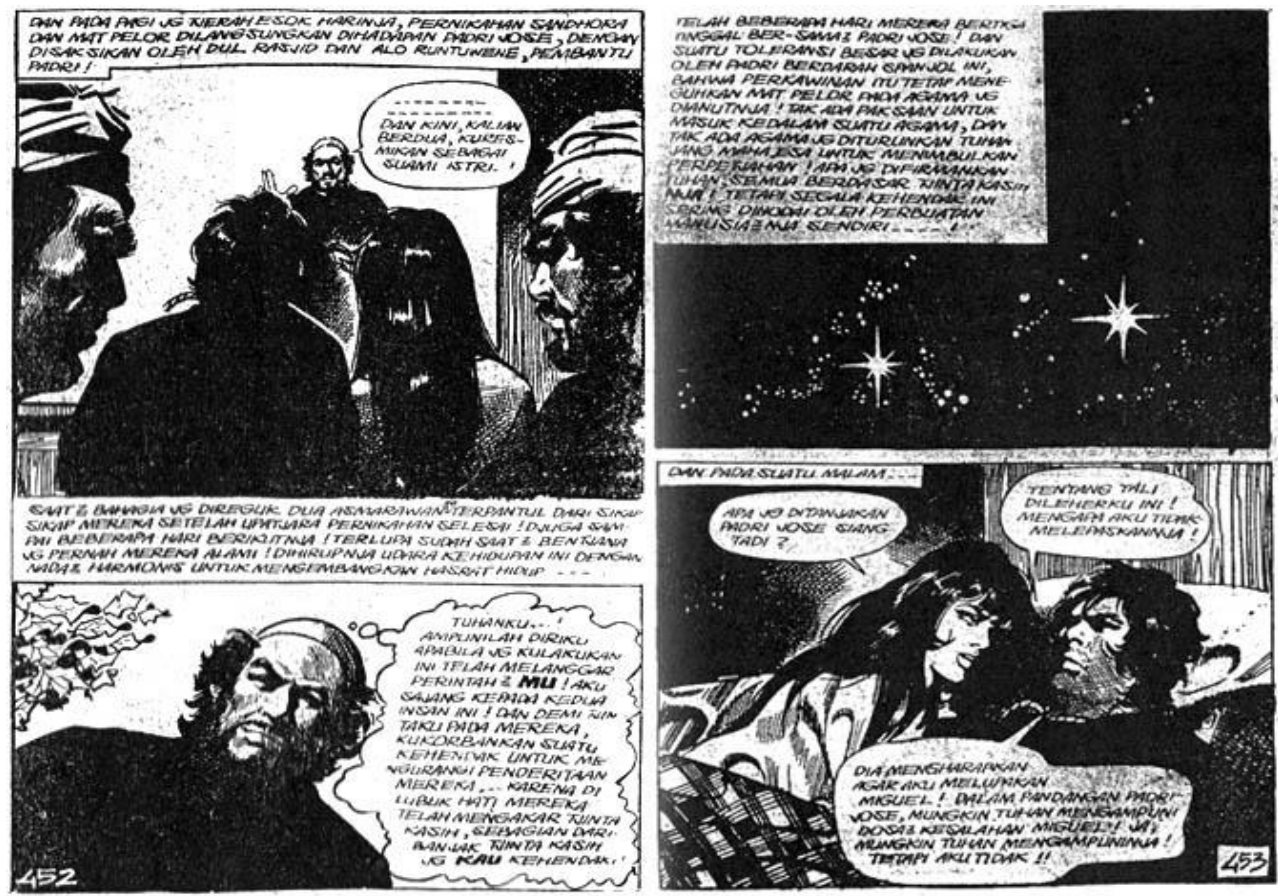

Gambar 6. Teguh memberikan peryataan evaluatif terhadap konflik-konflik yang kontradiktif dengan ajaran agama itu sendiri. [Sumber : Santoso, 1970] [7]

Disini Teguh menyatakan secara eksplisit bahwasanya pernikahan ialah peristiwa yang sakral dari sebuah cinta yang suci, sehingga kebahagian yang lahir daripadanya sanggup menutup segala luka dan duka. Lebih lanjut Teguh mengungkapkan pada balon pikiran pada panel kedua yang merupakan ucapan dalam benak Padri Jose Agualnido: "Tuhanku, ampunilah diriku, apabila jang kulakukan ini telah melanggar perintah-perintahMu! Aku sajang kepada dua insan ini! Dan demi cintaku kebada mereka kukorbankan suatu kehendak untuk mengurangi penderitaan mereka...Karena di lubuh hati mereka telah mengakar tjinta kasih, sebagian dari banjak tjinta kasih jang kau kehendaki". Dalam satuan peristiwa ini nampak bagaimana Teguh memposisikan tokoh Padri Jose sebagai agamawan dengan sikap toleransi yang tinggi dan mengedepankan cinta kasih ketimbang dogma-dogma kaku agama, dan selanjutnya dipertegas pada satuan peristiwa dalam halaman 453, Teguh mengungkapkan: "Telah beberapa hari mereka bertiga tinggal bersama-sama Padri Jose! Dan suatu toleransi besar jang dilakukan oleh Padri berdarah Spanjol ini, bahwa perkawinan itu tetap meneguhkan Mat Pelor pada agama jang dianutnja! Tak ada paksaan untuk masuk ke dalam suatu agama, dan tidak ada agama jang diturunkan Tuhan Jang Maha Esa 
untuk menimbulkan perpetjahan! Apa jang difirmankan Tuhan semua berdasar cinta kasihNja! Tetapi segala kehendak ini sering dinodai perbuatan manusia-manusianja sendiri...!". Pada kedua satuan peristiwa ini nampak sikap Teguh terhadap perbedaan ideologis.

Secara tematik terlihat bagaimana Teguh dalam Komik "Sandhora" ini mengangkat tema konsep dasar tentang kemanusiaan, di mana cinta yang tulus dan suci akan menemukan jalannya untuk bersatu, dan selama itu pula kebiadaban, kelicikan, dan keserakahan akan terus membayang-bayangi. Dengan menempatkan cinta kasih dalam perjuangan antara hidup dan mati, dan tidak ada cara lain, selain tetap berpijak pada kebenaran, ajaran kasih sayang dan nilai-nilai kemanusiaan. Tema ini juga terekespresikan dalam sikap Teguh dalam pokok-pokok pikiran yang telah ia sajikan, yakni dengan mengecam segala macam bentuk tindak kekerasan, kebiadaban, atau peperangan, baik itu yang disebabkan oleh hasrat akan kekuasaan dan keserakahan, ataupun dalih "perang suci" dengan mengatasnamakan agama. Sebaliknya, ia menyajikan kepada pembaca suatu pemahaman agama yang mengedepankan cinta kasih terhadap sesama manusia, menghargai perbedaan, serta toleransi, atau dengan perkataan lain semangat pluralisme dan multikulturalisme. Tema dan sikap yang dibangun oleh Teguh dalam komik ini menunjukkan komitmen yang kuat terhadap paradigma estetik Humanisme Universal.

Humanisme universal sendiri merupakan paham yang dianut oleh budayawan dan pengarang Indonesia yang tidak mendukung realisme sosialis. Unsur-unsur humanisme universal diungkapkan dengan jelas dalam surat Kepercayaan gelanggang dan diulang sekali dalam Manifesto Kebudayaan. Konsep humanisme universal adalah melihat diri sendiri dan karya mereka sendiri sebagai bagian dari kebudayaan dunia yang mengutamakan manusia sebagai makhluk yang sederajat. Burhan menyatakan bahwa pada paruh kedua 1960-an hingga tahun 1980-an, paradigma estetik humanisme universal menguat [25]. Seni rupa membebaskan penciptaan dari pengaruh politik. Penghargaan pada kesadaran pribadi dan kebebasan berekspresi mendorong penjelajahan individual untuk melahirkan ungkapan bentuk yang beragam. Adapun naskah Manifest Kebudayaan sebagaimana yang diungkapkan oleh Moeljanto dan Ismail adalah sebagai berikut: [26]

"Kami para seniman dan cendekiawan Indonesia dengan ini mengumumkan sebuah Manifes Kebudayaan yang menyatakan pendirian, cita-cita dan politik Kebudayaan Nasional kami. Bagi kami kebudayaan adalah perjuangan untuk menyempurnakan kondisi hidup manusia. Kami tidak mengutamakan salah satu sektor kebudayaan di atas sektor kebudayaan lain. Setiap sector berjuang bersama-sama untuk kebudayaan itu sesuai dengan kodratnya. Dalam melaksanakan Kebudayaan Nasional, kami berusaha menciptakan dengan kesungguhan yang sejujur-jujurnya sebagai perjuangan untuk mempertahankan dan mengembangkan martabat diri kami sebagai bangsa Indonesia di tengah masyarakat bangsa-bangsa".

"Pancasila adalah falsafah kebudayaan kami". 
Humanisme Teguh nampak dari bagaimana ia menyajikan tema tentang cinta yang tulus dan suci akan menemukan jalannya untuk bersatu, dan selama itu pula kebiadaban, kelicikan, dan keserakahan akan terus membayang-bayangi. Dengan menempatkan cinta kasih dalam perjuangan antara hidup dan mati, dan tidak ada cara lain, selain tetap berpijak pada kebenaran, kasih sayang dan nilai-nilai kemanusiaan. Universalitas Teguh juga nampak dari bagaimana ia mengutuk peperangan, serta menyajikan kepada pembaca suatu pemahaman agama yang mengedepankan cinta kasih terhadap sesama manusia, menghargai perbedaan, serta toleransi, atau dengan perkataan lain semangat pluralisme dan multikulturalisme. Disamping itu, melalui Komik "Sandhora" Teguh berupaya menempatkan kebudayaan nasional (Indonesia) secara bermartabat atau setara dengan kebudayaan bangsa lain, yang di dalam Komik "Sandhora" dengan bangsa Spanyol dan Belanda. Idiom-idiom religiusitas/spiritualitas Teguh juga mendapatkan tempat di Komik "Sandhora", sehingga dapat juga dikatakan bahwa Sandhora tidak hanya mengekspresikan humanisme, namun humanismereligius. Dalam paradigma estetik kontektualisme kerakyatan yang diusung oleh Lekra, tentunya idiom-idiom religiusitas benar-benar tidak mendapatkan tempat. Disamping itu, Komik "Sandhora" juga sarat idiom-idiom kebudayaan tradisional Indonesia, sebagai upaya pencarian identitas budaya nasional Indonesia, yang juga merupakan semangat humanisme universal, terutama yang diusung oleh kelompok Manikebu. Religius, humanis, dan memperjuangkan martabat kebudayaan nasional, itulah yang nampak dari Komik "Sandhora", sehingga secara spesifik Komik "Sandhora" memiliki komitmen kuat pada paham religio-humanisme universal.

\subsection{Interpretasi Ikonologis}

Pada bagian ini diketengahkan hasil sebagai jawaban dari pertanyaan penelitian ketiga yaitu bagaimanakah makna intrinsik yang membentuk nilai simbolik Komik "Sandhora" (1970) karya Teguh Santosa. Untuk menjawab pertanyaan ketiga ini dilakukan interpretasi ikonologis: suatu upaya untuk mengungkap makna intrinsik atau isi (intrinsik meaning/content), dengan jalan memastikan prinsip-prinsip apa yang mendasari, dan yang mengungkapkan sikap dasar dari suatu bangsa, periode, kelas, agama, atau filsafat, dimana karya seni tersebut diciptakan, yang mempengaruhi ideologi si pencipta seni. Interpretasi ikonologis, pada akhirnya membutuhkan lebih dari sekedar rasa familiar terhadap tema dan konsep tertentu yang diperoleh dari sumber literer. Dalam tahap ini dibutuhkan intuisi sintetis berupa rasa familiar terhadap dorongan-dorongan, atau tendesi-tendensi esensial manusia (seniman), yang dikondisikan oleh psikologi personal dan weltanschauung (pandangan hidup) si pencipta karya seni [13]. Dari pemaparan yang dilakukan pada tahap interpretasi ikonologis ini, nampak bagaimana psikologi personal dan weltanschauung (pandangan hidup) Teguh Santosa sebagai pencipta karya Komik "Sandhora". Dengan mengungkapkan sikap dasar dari bangsa Indonesia pada waktu itu, periode, kelas, agama, atau peristiwa yang terjadi pada waktu karya tersebut diciptakan, nampak bagaimana ideologi Teguh sebagai komikus. Hal ini sekaligus menjawab rumusan masalah penelitian yang kedua. Berangkat dari konsep simbol seni, Komik "Sandhora" merupakan sebuah simbol yang utuh yang notabene merupakan jiwa zaman. Melalui konstruksi argumen yang telah dipaparkan dalam interpretasi ikonologis diatas, maka 
Komik "Sandhora" (1970) merupakan kristalisasi simbol dari pembelaan terhadap nilainilai kemanusiaan/humanisme, kebebasan berekspresi, dan kesetaraan manusia, serta upaya perjuangan budaya, dalam rangka mempertahankan dan mengembangkan martabat diri bangsa Indonesia di tengah masyarakat global.

Di tahun '60-an, arena seni dan sastra menjadi medan perseteruan antara Lekra vs Manikebu. W.S. Rendra sang penyair dengan puisi-puisi pamflet yang menohok dan erotik dikala itu, menjadi bulan-bulanan Lekra, karena bagi Lekra penyair erotik harus menyingkir karena mereka adalah tidak lain adalah penggelap jalannya revolusi. Adapun hal yang cukup menarik, di tahun 1965, setelah Manikebu dipangkas oleh Soekarno, pada tanggal 10 Januari 1965, Lekra, melalui majalah "Lentera" Harian Bintang Timur mengeluarkan daftar musuhnya, dengan menyebutnya sebagai "Manikebuis Yogyakarta", dan nama Rendra tercantum disana. Rendra juga termasuk dalam Sastrawan Angkatan 45' yang mengusung humanisme universal, meskipun tidak terlibat secara langsung, Rendra sedikit banyak terhubung dengan Manikebu. Dalam karya-karya puisi Rendra juga sering dijumpai erotisme, yang menunjukkan bagaimana ia menjunjung tinggi kebebasan berekspresi sebagaimana yang diperjuangkan Wiratmo Soekito. Pada masa yang tidak terpaut jauh, erotisme, sentimen (ekspresi) pribadi, dan humanisme muncul dalam karya-karya Teguh, termasuk dalam Sandhora (1970). Erotisme agaknya menjadi sebuah 'syarat' dalam jargon kebebasan berekspresi. Gambar erotis dengan adegan pengumbaran syahwat menghiasi komik Teguh di era 70an, sempat membawa gusar petinggi penyetuju peredaran komik saat itu. Teguh pernah dipanggil secara pribadi dan diintrogasi oleh Seksi Bina Budaya Komdak Metro Jaya dan mendekam di penjara selama 3 hari untuk memperbaiki ulah sensasional di komiknya karena perwujudannya dianggap gampang "menerbitkan birahi" [27]. Mengenai hal ini, Teguh pernah berkomentar, seperti yang diingat oleh putranya Valiandra sebagai berikut :

"Bahwa kebebasan berekspresi adalah hak saya. Sebagai seorang komikus sama sekali tak punya niat menjual imajinasi yang vulgar...Lha wong proses sensual itu mengalir dengan alamiah sesuai cerita, masa orang tidak boleh lagi melihat adegan ciuman bibir?" [27]

Kebebasan berekspresi merupakan kondisi kebebasan kreatif yang dijiwai oleh semangat humanisme universal. Baik Teguh meupun Rendra sama-sama mengusung hal ini. Adapun hubungan Teguh dengan Rendra, dikatakan oleh Valiandra sebagai berikut :

"Teguh itu orang biasa, tapi karyanya luar biasa, seperti dikatakan W.S. Rendra - Teguh memanggilnya Mas Willy (panggilang akrab W.S. Rendra) - pada sebuah acara ulang tahun sanggar bambu di Yogyakarta. Disitu saya baru tahu ternyata seorang W.S. Rendra juga pembaca komik Teguh. Dulu bapak pernah bercerita saat di sanggar Bambu diajak pak Sunarto PR menggarap panggung untuk pementasan Bengkel Teater Rendra, lakon Oedipus Complexs". [27]

Disamping itu, dalam wawancara dengan Valiandra tanggal 2 September 2016, Valiandra juga mengungkapkan pernah diminta untuk mengirimkan paket oleh Teguh kepada Rendra yang isinya berupa komik yang cukup banyak. la juga melanjutkan bahwa Teguh mengobrol cukup lama dengan Rendra pada saat reuni Sanggar Bambu 
tahun 1997. Teguh bergabung di Sanggar Bambu pada tahun 1966, dan menurut Valiandra disinilah kesenimanan Teguh dibentuk, lewat tangan dingin pak Narto-lah (Sunarto P.R.) pematangan bentuk gaya-gaya goresan Teguh, seperti gaya arsir, gayagaya liris, dan juga tipografi tulisan. Di tahun itu umur Teguh 24 tahun, dan ia bersinggungan dengan begitu hebat dengan dunia sastra khususnya teater, yang sarat akan pertarungan ideologi. Dalam pengakuan Teguh kepada putranya Valiandra, Pak Narto-lah yang mengarahkannya untuk menjadi seorang ilustrator komik, karena di Yogya pada saat itu telah banyak anggota Sanggar Bambu yang menjadi pelukis. Sanggar bambu didirikan pada 1 April 1959 di Yogyakarta, tepatnya di Jl.Gendingan 119 oleh Sunarto P.R. bersama-sama dengan Kirdjomulyo, Heru Sutopo, Mulyadi W., Danarto, Soeharto Pr, Syahwil, Handogo, Soemadji dan Wardoyo. Mengenai hal ini, dalam majalah "Angkatan Bersendjata" yang terbit pada tahun 1968, halaman IV dalam artikel yang berjudul Sunarto $P R$ : Pelukis Merdeka, tertulis demikian :

"Demikianlah demi tanggungdjawabnja Sunarto Pr. memelihara sebuah grup pelukis2 jang dinamakan "Sanggarbambu" jang dirintis bersama dengan kawan2nja seperti Sjahwil, Muljadi, Wardojo, dsb. Dulu terutama bertudjuan sebagai wadah pelukis-pelukis jang non Lekra. Sanggarbambu dikenal dalam salah satu azasja jaitu kemerdekaan anggota2nja, atau boleh dikatakan bahwa Sanggarbambu adalah organisasi orang2 jang merdeka." [28]

Dalam ulasan tersebut nampak bahwa Sanggar Bambu pada awalnya ditujukan sebagai wadah seniman-seniman yang non-Lekra, dengan kata lain sebagai wadah seniman yang tidak mengusung atau tidak sepakat dengan paradigma estetik kontektualisme kerakyatan, atau kerakyatan yang revolusioner. Selanjutnya dikatakan bahwa Sanggar Bambu dikenal dengan azasnya yaitu kemerdekaan anggota-anggotanya, atau organisasi orang-orang merdeka. Kemerdekaan yang dimaksud disini adalah dalam konteks berkarya seni, yakni kebebasan berekspresi tanpa hegemoni sikap-sikap atau pandangan politis. Lebih lanjut sikap apolitis, universal, dan dukungan terhadap kebebasan berekspresi dalam berkarya seni Sunarto PR diungkapkan pula pada wawancara jurnalis majalah Sinar Harapan pada tahun 1969, pada halaman vi-vii, dalam artikel yang berjudul "Sunarto PR : Sebuah Profil", ia menyatakan bahwa di Sanggar Bambu pun dapat dijumpai pelukis-pelukis abstrak, ekspresionis, dan "lain-lain isme", serta bagaimana setiap anggota Sanggar Bambu bisa saling belajar mengenai gaya [29]. Hal ini sebagaimana yang diungkapkan oleh Burhan, pada periode ketiga, pada paruh kedua 1960-an hingga tahun 1980-an, paradigma estetik humanisme lebih mendorong semangat penjelajahan yang melahirkan bentuk-bentuk seni lukis abstrak dan kecenderungan lainnya [25]. Pada masa itu kreativitas dalam seni lukis atau pada seni rupa Indonesia dipenuhi oleh berbagai aliran dan gaya pribadi. Mengenai sikap apolitis, universal, dan dukungan terhadap kebebasan berekspresi dalam berkarya seni, tahun 2003 Sunarto PR kembali menegaskannya kembali dalam wawancara oleh Utari Dewi Narwanti (Yayasan Seni Cemeti) pada tanggal 28 Mei 2003, di Yogyakarta, ia mengatakan demikian :

"...Makanya Sanggar Bambu lahir dengan non politik. Lekra kan dari tahun 51, paling tua, maka yang lain iri malahan, kan mesti menandingi kan gitu, menandingi. Maka Sanggar Bambu non politik, gitu". [30] 
Dalam pernyataan Sunatro PR diatas terlihat bahwa Sanggar Bambu didirikan salah satunya adalah untuk menandingi Lekra, yang berarti memiliki landasan ideologis yang berseberangan dengan Lekra, sekaligus "non-politik". Hal ini juga seperti apa yang diungkapkan oleh Burhan, bahwa meskipun Sanggar Bambu didirikan bukan pada saat Orde Baru, namun kesenian (seni rupa) pada awal Orde Baru berusaha secara murni membebaskan penciptaan dari pengaruh-pengaruh politik, sebagai antitesis terhadap kecenderungan paham kerakyatan revolusioner (Lekra menegaskan paham ini lewat kredo "Satu Lima Satu") yang sebelumnya sangat dominan dan politikal [25]. Masamasa tersebut merupakan masa dimana humanisme universal berkembang dengan subur. Dari sini nampak bagaimana Sunarto PR dengan Sanggar Bambunya memiliki halauan humanisme universal, sehingga tidak heran jika kemudian Teguh melalui karyanya memiliki komitmen yang cukup kuat terhadap paradigma estetik humanisme universal, karena Sunarto PR merupakan orang yang memiliki pengaruh cukup besar terhadap kesenimanan Teguh, dengan Sanggar Bambu sebagai "Kawah Candradimuka"-nya. Sebagaimana Teguh, Sunarto PR juga melihat sajian erotisme dalam seni sebagai sebuah bentuk kebebasan berekspresi dan sebagai "kehidupan kreatif" seniman.

Tidak hanya kepada Sunarto PR, di Sanggar Bambu, Teguh juga belajar kepada Kentardjo (Ilustrator cerita silat karya-karya SH. Mintardja), Abdul Salam (Komikus cerita perjuangan, dan Syahwil [27]. Adapun Syahwil ini juga disebut dalam majalah "Angkatan Bersendjata" sebagai perintis Sanggar Bambu bersama Sunarto PR [28]. Kentardjo merupakan seniman grafis angkatan 1930-an, wafat pada tanggal 3 Maret 2003. Dewan Revolusi pada tanggal 2 Oktober 1965, satu hari setelah dekrit didirikannya, melakukan represi terhadap harian Kedaulatan Rakyat (KR) (Tim Ensiklopedi Pers Indonesia, 2012). Represi dan ancaman penutupan ini tentunya bukan tidak tanpa alasan, tentunya karena ideologi yang berseberangan. Dewan Revolusi mengganggap KR sebagai "kontra-revolusi" versi Dewan Revolusi. Namun KR melakukan resistensi dengan tetap bertahan dan terbit meskipun di bawah ancaman, dan mengganti namanya menjadi Dwikora, yang dapat dipahami sebagai sebuah bentuk dukungan kepada kabinet Dwikora yang didemisionerkan oleh Dewan Revolusi. Dari sini dapat dilihat bagaimana halauan harian Kedaulatan Rakyat pada masa itu, ia berada pada "sayap kanan", yang pro-Dwikora, kontra-Dewan Revolusi, dan Kentardjo pada masa itu berada disana (bekerja di harian KR). Sikap "sayap kanan" Kentardjo juga ditunjukkan ketika ia juga bergabung dengan Sanggar Bambu yang kontra-Lekra, dan berideologi humanisme-universal. Di harian Kedaulatan Rakyat, Kentardjo juga mengalami apa yang dinamakan sebagai "represi sayap kiri". Adapun Abdul Salam, mencatatnya sebagai pelopor komik Indonesia di tahun 50-an [6]. Abdul Salam terus memasok komiknya setiap Minggu ke harian Kedaulatan Rakyat yang terbit di Yogyakarta.

Sebelum di Sanggar Bambu, masa kecil Teguh hidup di lingkungan grup ketoprak Tobong Kridosworo miliki keluarga besarnya, dengan pimpinan Ki Siswondo HS (Pak Sis). Menurut pengakuan Valiandra dalam wawancara tanggal 2 September 2016, Ki Siswondo HS dengan grup ketoprak Kridosworo-nya pernah ditawari untuk bergabung 
dengan Lekra, dan Ki Siswondo HS menolak. Akhirnya grup tersebut bubar pada tahun 1965 atas inisiatif keluarga, karena kekhawatiran, dimana pada saat itu konflik ideologis sudah mulai mencapai puncaknya. Menurut Valiandra, banyak pula kerabat Teguh yang dituduh Lekra hingga pada pasca peristiwa 65 kemudian dikenakan wajib lapor ke Koramil Kepanjen. Tuduhan-tuduhan sebagai PKI, Komunis, ataupun Lekra memang terjadi pada peristwiwa 65 yang lebih mirip seperti genosida ini, banyak orang dihakimi bahkan dibunuh tanpa ada proses pengadilan. Hal yang sama juga menimpa banyak dari keluarga Teguh. Tekanan psikologis di tengah-tengah konflik ideologi dan kebudayaan yang dialami oleh Teguh ini dapat dipahami dari wawancara kepada Dhany Valiandra pada tanggal 2 September 2016, ia menyatakan sebagai berikut :

"Keluarga takut aja, waktu itu gerakan PKI memang sudah memuncak dan perang dengan ABRI, bapak (Teguh) cerita waktu itu daerah Malang Kepanjen banyak juga pembunuhan, bahkan warga Tionghoa di Kepanjen ada yang ditusuk sampai mati, ini cerita bapak. Banyak orang yang tidak sadar bahwa nasionalisme juga bisa dibangun dari seni komik waktu itu, seni propaganda melawan kompeni luar biasa. Tapi ketika bergerak untuk melawan bangsa sendiri yang PKI, perlawanan dari PKI sangat ngeri. [27]

Meskipun tidak mengalami represi langsung dari kelompok politik sayap kiri, namun hal ini cukup dapat menjadi tekanan psikologis bagi Teguh, dan akhirnya turut mempengaruhi sikap Teguh yang apolitis, dan kemudian bergabung dengan Sanggar Bambu, serta turut menyuarakan humanisme universal. Mengenai kecenderungan dan komitmen Teguh dalam menyuarakan humanisme universal, serta Sanggar Bambu yang juga berparadigma estetik humanisme universal, Valiandra mengonfirmasinya dalam wawancara tanggal 7 September 2016, ia mengungkapkan demikian :

"Lulus SMA (1966), bapak ngglandang ke Jogja bergabung dengan Sanggar Bambu yang kondhangnya sampai Jatim, markas seniman berideologi untuk Indonesia, bergerak dalam Manifest Kebudayaan".

Valiandra juga melanjutkan, bahwa Teguh tidak mau terjun dalam ranah politik praktis. Memang tidak perlu menjadi Manikebu untuk dapat menyuarakan humanisme universal, sedangkan Manikebu sendiri merupakan gerakan politik kebudayaan. Dari pemaparan yang dilakukan pada tahap interpretasi ikonologis ini, nampak bagaimana psikologi personal dan weltanschauung (pandangan hidup) Teguh Santosa sebagai pencipta karya Komik "Sandhora". Dengan mengungkapkan sikap dasar dari bangsa Indonesia pada waktu itu, periode, kelas, agama, atau peristiwa yang terjadi pada waktu karya tersebut diciptakan, nampak bagaimana ideologi Teguh sebagai komikus. Hal ini sejalan dengan apa yang diungkapkan oleh Langer mengenai simbol seni, dimana karya seni, secara utuh merupakan sebuah bentuk simbol, yang merupakan citra atau ekspresi perasaan seniman, dengan kata lain sebagai "presentasi" perasaan dan emosi seniman [31]. Berangkat dari konsep tersebut, Komik "Sandhora" merupakan sebuah simbol yang utuh yang notabene merupakan jiwa zaman. Melalui konstruksi argumen yang telah dipaparkan dalam interpretasi ikonologis diatas, maka Komik "Sandhora" (1970) merupakan kristalisasi simbol dari pembelaan terhadap nilainilai kemanusiaan atau humanisme, kebebasan berekspresi, dan kesetaraan manusia, 
serta upaya perjuangan budaya, dalam rangka mempertahankan dan mengembangkan martabat diri bangsa Indonesia di tengah masyarakat bangsa-bangsa (global).

\section{KESIMPULAN}

Kesimpulan yang didapatkan dari deskripsi pra-ikonografis dan analisis ikonografis adalah bahwa Komik "Sandhora" (1970) karya Teguh Santosa merupakan kisah cinta antara dua tokoh utama yakni Sandhora dan Mat Pelor. Cerita komik ini mengisahkan perjalanan tokoh utama yang penuh dengan konflik dan ketegangan karena gesekan/benturan dengan para tokoh antagonis. Aspek faktual ini terbentuk melalui relasi antar elemen komik berupa dinamika setting tempat, waktu, dan setting psikologis yang cukup kompleks, titik pandang narrator omniscient, genre roman petualangan-sejarah, gaya gambar ketepatan obyektif, serta gaya personal berupa teknik arsir dan blok hitam. Pendekatan ketepatan obyektif ini cukup populer dalam komik pada tahun 60an, 70an hingga 80an, dan juga nampak pada komikus dan karya komik yang lain yang sezaman, semisal Ganes TH dalam karyanya "Si Buta dari Goa Hantu" (1968), dan Hans Jaladara dalam karyanya "Panji Tengkorak" yang terbit pertama kali tahun 1967. Meskipun sama-sama menggunakan pendekatan yang sama, nampak bagaimana Teguh memiliki kemampuan teknis yang lebih akurat dalam hal mewujudkan obyek gambar dengan lebih obyektif (memiliki kesamaan kualiatif yang lebih tinggi dengan obyek yang diacunya), begitu juga dalam hal kompleksitas elemen (detail) dan komposisi. Adapun genre komik ini adalah roman petualangan dan roman sejarah, atau roman petualangan-sejarah. Genre yang sama nampak pada karya komik "Taufan" (1973) karya Ganes TH dengan setting waktu masa revolusi kemerdekaan Indonesia, atau "Njai Dasima" (1969) karya Yus Chandra dengan setting tahun 1820-an di Jakarta (Betawi). Penggambaran ekpresional dalam komik ini mengungkapkan sebuah kisah cinta dan petualangan yang penuh dengan ketegangan, pertarungan antara hidup dan mati, kelicikan, kekesatriaan, dan harapan, yang diekspresikan melalui penokohan dan perwatakan, alur, sudut pandang, setting waktu, tempat, dan peristiwa, serta tentunya gaya gambar personal Teguh, berupa teknik blok hitam yang turut menguatkan ekspresi ketegangan dalam komik ini.

Elemen-elemen visual dan verbal, baik yang bersifat faktual maupun ekspresional tersebut membentuk tema berupa konsep dasar tentang kemanusiaan, dimana cinta yang tulus dan suci akan menemukan jalannya untuk bersatu, dan selama itu pula kebiadaban, kelicikan, dan keserakahan akan terus membayang-bayangi, dengan menempatkan cinta kasih dalam perjuangan antara hidup dan mati. Dan tidak ada cara lain, selain tetap berpijak pada kebenaran, ajaran kasih sayang, religiusitas, dan nilainilai kemanusiaan. Tema ini juga terekespresikan dalam sikap Teguh dalam pokokpokok pikiran yang telah ia sajikan, dengan menyajikan kepada pembaca suatu pemahaman agama yang mengedepankan cinta kasih terhadap sesama manusia, menghargai perbedaan, serta toleransi, atau dengan perkataan lain semangat pluralisme dan multikulturalisme. Tema dan sikap yang dibangun oleh Teguh dalam komik ini menunjukkan komitmen yang kuat terhadap paradigma estetik humanisme universal, yang populer pada paruh kedua 1960-an hingga tahun 1980-an, 
Dari pemaparan yang dilakukan pada tahap interpretasi ikonologis ini, nampak bagaimana psikologi personal dan weltanschauung (pandangan hidup) Teguh Santosa sebagai pencipta karya Komik "Sandhora". Dengan mengungkapkan sikap dasar dari bangsa Indonesia pada waktu itu, periode, kelas, agama, atau peristiwa yang terjadi pada waktu karya tersebut diciptakan, nampak bagaimana ideologi Teguh sebagai komikus. Berangkat dari konsep simbol seni, Komik "Sandhora" merupakan sebuah simbol yang utuh yang notabene merupakan jiwa zaman. Melalui konstruksi argumen yang telah dipaparkan dalam interpretasi ikonologis diatas, maka Komik "Sandhora" (1970) merupakan kristalisasi simbol dari pembelaan terhadap nilai-nilai kemanusiaan/humanisme, kebebasan berekspresi, dan kesetaraan manusia, serta upaya perjuangan budaya, dalam rangka mempertahankan dan mengembangkan martabat diri bangsa Indonesia di tengah masyarakat global.

\section{DAFTAR PUSTAKA}

[1] Eisner, Will, 2000. Comics \& Sequential Art. Florida : Poorhouse Press.

[2] Suroto, Surjorimba. 2007. Pengantar Kuratorial, dalam katalog Pameran Komik Indonesia Satu Dekade (KONDE), 9-18 Agustus 2007 di Bentara Budaya Jakarta. Jakarta : Akademi Samali.

[3] Lubis, I. 2009. Komik Fotokopian Indonesia 1998-2001. Jurnal Visual Art \& Desain. Vol. 3, No. 1. Hal 57-78. Bandung: ITB

[4] Atmadiredja, Genardi. 2012. Komik Di Indonesia: Sebuah Studi Perbandingan Antara Komik Lokal Dengan Komik Asing. Url: https://www.academia.edu/5078769/KOMIK_DI_INDONESIA_SEBUAH_ST UDI_PERBANDINGAN_ANTARA_KOMIK_LOKAL_DENGAN_KOMIK_ASING [diakses pada 20 Agustus 2016]

[5] Kasmana, dkk. 2014.

[6] Bonneff, Marcel. 1998. Komik Indonesia. Jakarta : Kepustakaan Populer Gramedia.

[7] Santosa, Teguh. 1970. Sandhora, Jilid 1-10. Jakarta : UP. Pantjar Kumala.

[8] McGrath, Alister E. Sejarah Pemikiran Reformasi. Jakarta: BPK Gunung Mulia.

[9] Abbagnano, N. 1967. The Encyclopedia of Philosophy Vol. 3. New York: Macmillan Publishers

[10] Suseno, Franz M. 2003. Manusia dan Kemanusiaan dalam Perspektif Agama. Jogjakarta: Penerbit Jendela.

[11] Hadi, Sofyan. 2012. Kebhinekaan dalam Beragama. Url: https://www.academia.edu/24141066/Kebhinekaan_dlm_Beragama [diakses pada 20 Agustus 2016]

[12] Madjid, M. Dien \& Johan Wahyudi. 2014. Ilmu Sejarah : Sebuah Pengantar. Jakarta: Prenada Media Group

[13] Panofsky, Erwin. 1955. Meaning of The Visual Arts. New York : Doubleday Anchor Books.

[14] Abdurrahman, Dudung. 1999. Metode Penelitian Sejarah. Ciputat: Wacana IImu.

[15] Moleong, Lexy J. 2014. Metodologi Penelitian Kualitatif. Bandung : Rosda.

[16] Wicaksono, Andri. 2014. Pengkajian Prosa Fiksi. Yogyakarta : Penerbit Garudhawacana. 
[17] Aminuddin, 2014. Pengantar Apresiasi Karya Sastra. Bandung : Sinar Algesindo.

[18] Feldman, Edmund Burke, 1967. Arts as Image and Idea. New Jersey : Prentice Hall.

[19] TH, Ganes. 1968. Si Buta dari Goa Hantu : Misteri Borobudur. Jakarta : Pustaka Satria Sejati.

[20] Syarifuddin. 2015. Mengingat-ingat Teguh Santosa (1942-2000), dalam Abdul Malik dan S. Jai (Eds.) Sebuah Antologi : Maestro of The Darkness, Teguh Santosa 1942-2000, Malang : Penerbit Media Nusa Creative, pp. 89-96.

[21] Ruttkowski W. \& Reichmann E, 1974. Das Studium der Deutschen Literatur. Philadelphia : National Carl Schurz Association.

[22] Bittner, Wolfgang, 2006. Das Abenteuer in der Literatur. Dalam Bittner (Ed) Schreiben, Lesen, Reisen. ISBN 978-3-89896-253-7. Oberhausen 2006, pp. 53-60.

[23] Robbins, Stephen P. 2007. Perilaku Organisasi. Buku 1. Jakarta : Salemba Empat.

[24] Breckler, S. J. 1984. Empirical Validation of Affect, Behavior, and Cognition as Distinct Component of Attitude. Journal of Personality and Social Psychology.

[25] Burhan, M. Agus, 2003. Seni Rupa Modern Indonesia : Tinjauan Sosiohistoris. Dalam Wicaksono, Adi dkk. (Eds.) Aspek Seni Visual Indonesia: Politik dan Gender. Yogyakarta : Yayasan Seni Cemeti, pp. 19-45.

[26] Moeljanto, D.S. \& Taufiq Ismail. 1995. Prahara Budaya: Kilas-Balik Ofensif Lekra/PKI Dkk. Bandung : Mizan.

[27] Valiandra, Dhany. 2015. Serpihan Kenangan Menemani Bapak Sebagai Seorang Komikus, dalam Abdul Malik dan S. Jai (Eds.) Sebuah Antologi : Maestro of The Darkness, Teguh Santosa 1942-2000. Malang : Penerbit Media Nusa Creative, pp. 1-36.

[28] Angkatan Bersendjata. 1968. Sunarto $P R$ : Pelukis Merdeka, p. IV. URL : http://archive.ivaa-online.org/khazanahs/detail/1946 [diakses pada 26 Agustus 2016].

[29] Winarto, Jasso. 1969. Sunarto PR : Sebuah profil. Dalam Sinar Harapan, pp. VI-VII. URL : http://archive.ivaa-online.org/khazanahs/detail/1900 [diakses pada 26 Agustus 2016].

[30] Narwanti, Utari Dewi. 2003. Wawancara Yayasan Seni Cemeti dengan Sunarto PR tentang Sanggar Bambu. URL : http://archive.ivaaonline.org/khazanahs/detail/1957 [diakses pada 20 Agustus 2016]

[31] Langer, Suzanne K., 2006. Problematika Seni. Bandung : Sunan Ambu Press, STSI Bandung. 